\title{
KIR2DL1 wt Allele
}

National Cancer Institute

\section{Source}

National Cancer Institute. KIR2DL1 wt Allele. NCI Thesaurus. Code C129018.

Human KIR2DL1 wild-type allele is located in the vicinity of 19q13.4 and is approximately

$15 \mathrm{~kb}$ in length. This allele, which encodes killer cell immunoglobulin-like receptor 2DL1

protein, plays a role in the regulation of the immune response. 